\title{
Vegetation characteristics of bowé in Benin (West Africa)
}

\section{Elie Antoine Padonou1, *, Aristide Cossi Adomou², Yvonne Bachmann ${ }^{3}$, Anne Mette Lykke Brice Sinsin ${ }^{1}$}

${ }^{1}$ Faculty of Agronomic Sciences, University of Abomey-Calavi, Abomey-Calavi, Benin

${ }^{2}$ National Herbarium, Faculty of Sciences and Technics, University of Abomey-Calavi, Abomey-Calavi, Benin

${ }^{3}$ Institute of Ecology, Evolution and Diversity, J.W. Goethe University, Frankfurt am Main, Germany

${ }^{4}$ Department of Bioscience, Aarhus University, Silkeborg, Denmark

\section{Email address:}

padonouelie@yahoo.fr (E. A. Padonou), adomouaristide@yahoo.fr (A. C. Adomou), bachmann@bio.uni-frankfurt.de (Y. Bachmann), aml@dmu.dk (A. M. Lykke), bsinsin@gmail.com (B. Sinsin)

\section{To cite this article:}

Elie Antoine Padonou, Aristide Cossi Adomou, Yvonne Bachmann, Anne Mette Lykke, Brice Sinsin. Vegetation Characteristics of Bowé in Benin (West Africa). Journal of Plant Sciences. Vol. 2, No. 5, 2014, pp. 250-255. doi: 10.11648/j.jps.20140205.27

\begin{abstract}
Bowé are particular form of degraded land where ferricrete, a hard erosion-resistant layer, is exposed. This study investigated vegetation characteristics of bowé (species composition, life form, chorological type, and plant family) in the semiarid and sub-humid climate zones in Benin. In both climate zones, bowé sites were characterized by grassland and savanna. The species composition on bowé varied according to the climate zone. Woody species were frequent on bowé in sub-humid (51\% of the total species recorded) than in semiarid (44\%). Geophytes, hemicryptophytes and phanerophytes were frequent on bowe in the sub-humid than in the semiarid climate zone. The difference between the two climate zones on the occurrence of therophytes on bowé was not significant. The frequency of chamaephytes was higher on bowé sites in the semiarid zone. Afro-tropical, Afro-Malgache, Pluri regional African and Pantropical chorological types were frequent on bowé than in woodlands in each climate zone while the opposite was found for Guineo-Congolian and Sudano-Zambesian chorotypes. Plant families such as Amaranthaceae, Zingiberaceae, Chrysobalanaceae, Connaraceae, Loganiaceae, Moraceae and Ochnaceae were only found on bowé in the sub-humid climate zone, while Convolvulaceae, Loganiaceae, Rhamnaceae, Araceae, Colchicaceae, Cucurbitaceae, Olacaceae, Pedaliaceae, Amaranthaceae, and Cyperaceae were only found on bowé in the semiarid zone.
\end{abstract}

Keywords: Bowal, Ferricrete, Climate Zone, Species Composition, Life Form, Chorological Type, Plant Families

\section{Introduction}

In West Africa, distinctive landscapes exist where ferricrete, a hard erosion-resistant layer, is exposed. An area with exposed ferricrete (Fig. 1) is called bowal (plural bowé) $[4,6,10]$. Bowalization can be a natural process $[4,28]$ or human induced $[6,10,20]$. Bowé retain nearly no moisture $[4$, 10] so the vegetation on bowé desiccates quickly and burns by early fires in the dry season. The soils rapidly absorb and reradiate solar energy, thus during the dry season bowé are extremely hot and barren [10]. Bowé impede root growth and resist water absorption $[8,11,23,29]$ so that trees become dwarfed, gnarled and widely scattered.

The vegetation observed on bowé is poor in species and dominated by therophytes life form $[19,31]$. Thus one could expect particular vegetation characterictics on bowé since soil conditions influence species composition [14, 27], chorological type and life form [16, 19].
In Benin, bowé are found in both semiarid and sub-humid climate zones [21]. Since bowé are a particular form of degraded land, one could expect the same vegetation characteristics in the two climate zones. Thus, this study aims at assessing the vegetation characteristics of bowé; species composition, life form, chorological type and plant family composition in semiarid and sub-humid climate zones in Benin.

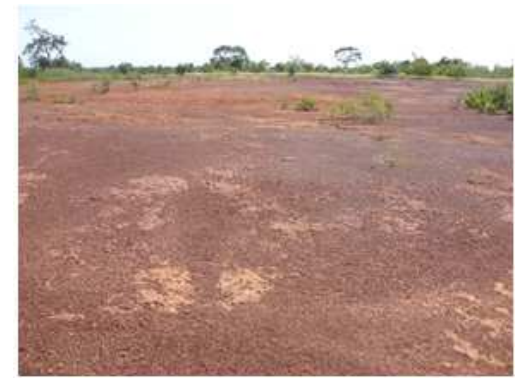

Fig. 1. Typical bowal surface in dry season 


\section{Material and Methods}

\subsection{Study Area}

The study was conducted in two climate zones in Benin where bowé are distributed [21]: the semiarid zone (between the latitudes $9^{\circ} 45^{\prime} \mathrm{N}-12^{\circ} 25^{\prime} \mathrm{N}$ and longitudes $0^{\circ} 45^{\prime} \mathrm{E}-3^{\circ} 55^{\prime} \mathrm{E}$ ) and the sub-humid zone (between the latitudes $7^{\circ} 30^{\prime} \mathrm{N}-9^{\circ} 45^{\prime}$ $\mathrm{N}$ and longitudes $\left.0^{\circ} 45^{\prime} \mathrm{E}-3^{\circ} 55^{\prime} \mathrm{E}\right)$. Data were collected in the phytogeographical districts of Mekrou-Pendjari in the semiarid zone and Zou in the sub-humid zone (Fig. 2). In the semiarid zone, the rainfall regime is unimodal with one rainy season from April to October. Mean annual rainfall varies from 785 to $1000 \mathrm{~mm}$ and relative humidity from 18 to $99 \%$ (being highest in August and lowest in February). Mean annual temperature ranges from 24 to $31{ }^{\circ} \mathrm{C}$. Hydromorphic, well drained, ferruginous soils and lithosols are the major soil types here. The rainfall distribution in the sub-humid zone is unimodal. The rainy season starts in April and ends in October. The mean annual rainfall range is $900-1110 \mathrm{~mm}$. The relative humidity from 31 to $98 \%$ and the mean annual temperature ranges from 25 to $29{ }^{\circ} \mathrm{C}$. Soils in this zone are ferruginous with variable fertility. The natural vegetation of the two zones is characterized by a mosaic of woodlands, dry dense forests, tree and shrub savannas and gallery forests.

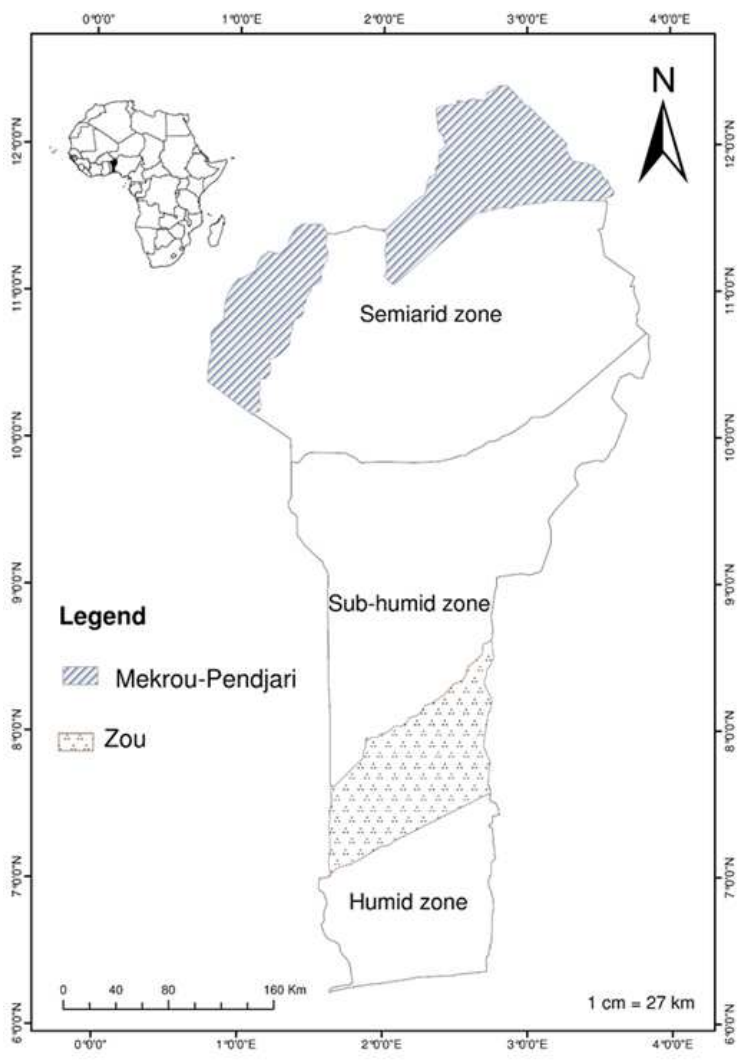

Fig. 2. Study area

\subsection{Data Collection}

In total 72 sampling plots $(30 \mathrm{~m} \times 30 \mathrm{~m})$ were established, half of them in the semiarid and the other half in the sub-humid climate zone. In each climate zone, 18 of the 36 sampling plots were set up on bowé sites and 18 in woodlands for reference (control plot). The presence of all woody species was identified in the $30 \mathrm{~m}$ x $30 \mathrm{~m}$ plots. In every plot, five sub-plots $(10 \mathrm{~m} \times 10 \mathrm{~m})$ were placed in the four corners and in the center where the presence of all herbaceous species was noted. On each plot, vegetation type and the dominant species were recorded. Life form, chorological type and plant family were noted. The data were collected at the end of the rainy season (October) when the bowé sites were $90 \%$ covered with vegetation. Species were determined by botanists of the National Herbarium of Benin. Species nomenclature [5], life form [2, 13, 25] and chorological types [30] were considered.

\subsection{Data Analysis}

The difference in species composition between bowé and woodlands in the two climate zones was computed using the Jaccard's similarity coefficient [15], which is given by the formula:

$$
P j=c /(a+b-c)
$$

Where $\mathrm{Pj}$ is Jaccard's community coefficient, a is the number of species present in the community $\mathrm{A}, \mathrm{b}$ is the number of species in the community $\mathrm{B}$, and $\mathrm{c}$ is the number of species shared by $\mathrm{A}$ and $\mathrm{B}$. The computation was automatically performed with the software CAP [22]. Plant communities were dissimilar if $\mathrm{Pj} \leq 0.5$.

Two-way ANOVA was used to test if the climate zones have an effect on the vegetation characteristics (life forms and chorological types), if the vegetation types (vegetation on bowé vs. woodlands) have an effect on the vegetation characteristics and finally if the interaction between climate zones and vegetation types have an effect on the vegetation characteristics using $\mathrm{R}$ software [26] as data were normally distributed. Post-hoc t-test was used to test if the vegetation characteristics (life forms and chorological types) on bowé were different between the climate zones.

\section{Results}

\subsection{Species and Plant Family Composition on Bowé}

In both climate zones, bowé sites are characterized by grassland and savanna; the tree cover being no more than $15 \%$ (Fig. 3). The woody species are frequent on bowe in the sub-humid zone $(51 \%$ of the total species recorded) than in semiarid zone ( $44 \%$ of the total species recorded). The species composition on bowé varies according to the climate zone. The similarity $\mathrm{Pj}$ in species composition between semiarid and sub-humid zone is 0.12 . In the semiarid climate zone, the dominant woody species on bowé are Acacia macrostachya Rchb. ex DC., Combretum glutinosum Perr. ex DC., Combretum nigricans Lepr. ex Guill. \& Perr. var. elliotii (Engl. \& Diels) Aubrév., Combretum collinum Fresen., Strychnos spinosa Lam., Cassia sieberiana DC., Ziziphus mucronata Willd. subsp. mucronata, Lannea microcarpa Engl. \& Krause, Anogeissus leiocarpa (DC.) Guill. \& Perr. The herb layer is dominated by Aristida kerstingii Pilger, Loudetiopsis 
kerstingii (Pilg.) Conert, Aristida stipoides Lam., Lepidagathis alopecuroides (Vahl) R.Br. ex Griseb., and Lepidagathis collina (Endl.) Milne-Redh.

In the sub-humid climate zone the dominant woody species on bowé are Combretum nigricans Lepr. ex Guill. \& Perr. var. elliotii (Engl. \& Diels) Aubrév., Combretum collinum Fresen., Detarium microcarpum Guill. \& Perr., Daniellia oliveri (Rolfe) Hutch. \& Dalziel, while the dominant herb species are Hyparrhenia welwitschii (Rendle) Stapf, Indigofera bracteolata DC., Oldenlandia corymbosa L., Chlorophytum macrophyllum (A.Rich.) Aschers.

The plant families observed on bowé in both zones are Poaceae, Rubiaceae, Combretaceae, Fabaceae, Acanthaceae, Vitaceae, Malvaceae, Lamiaceae, Euphorbiaceae, Annonaceae, Verbenaceae, Liliaceae, Commelinaceae, Cochlospermaceae, Asteraceae and Anacardiaceae. Families only found on bowé in the sub-humid zone are Amaranthaceae, Zingiberaceae, Chrysobalanaceae, Connaraceae, Loganiaceae, Moraceae and Ochnaceae; while Convolvulaceae, Loganiaceae, Rhamnaceae, Araceae, Colchicaceae, Cucurbitaceae, Olacaceae, Pedaliaceae, Amaranthaceae, and Cyperaceae are exclusively found on bowé in semiarid zone.

In the sub-humid climate zone, Malvaceae, Olacaceae, Convolvulaceae, Sapotaceae, Sapindaceae, Rhamnaceae, Pontederiaceae, Salicaceae, Ebenaceae, Dioscoreaceae, Clusiaceae, Boraginaceae, Bignoniaceae, Araliaceae, Apocynaceae, Rubiaceae, Ochnaceae and Lamiaceae are only observed in woodlands.

In the semiarid zone, Rubiaceae, Bignoniaceae, Chrysobalanaceae, Connaraceae, Convolvulaceae, Dioscoreaceae, Ebenaceae, Moraceae, Opiliaceae, Sapindaceae, Zingiberaceae are exclusively found in woodlands.

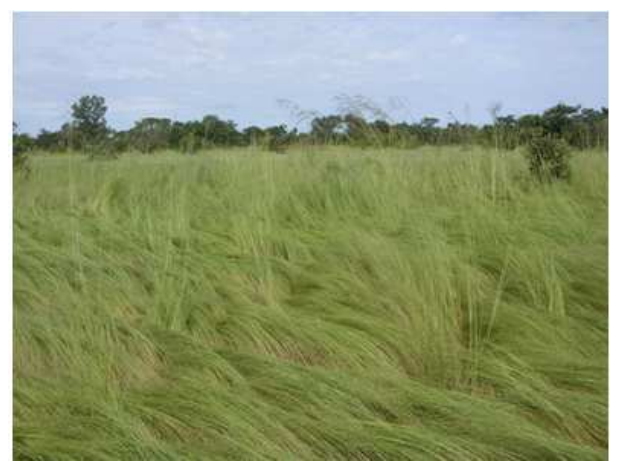

Fig. 3. Sample of vegetation on bowé in the semiarid zone dominated by Aristida kerstingii

\subsection{Effect of Bowalization on Species, Life Form and Chorological Type}

Plant species composition on bowé is not similar to that of woodlands $(\mathrm{Pj}=0.42$ in the sub-humid climate zone and $\mathrm{Pj}=$ $0.38<0.5$ in the semiarid climate zone). The woody species are frequent in woodlands ( $70 \%$ of the total species recorded in the sub-humid zone and $62 \%$ in the semiarid zone) than on bowe $(51 \%$ of the total species recorded in the sub-humid zone and $44 \%$ in the semiarid zone).

The output of the two-way ANOVA reveals significant difference between semiarid zone vs. sub-humid zone and bowé vs. woodlands on the occurrence of hemicryptophytes, chamaephytes, and phanerophytes (Table 1). Phanerophytes and hemicryptophytes are frequent in sub-humid than in semiarid while the opposite is found for chamaephytes and geophytes (Fig. 4). The interaction between the climate zones and the vegetation types is signification for the occurrence of geophytes, chamaephytes and therophytes. However, we could not conclude that there is an interaction between the climate zones and the vegetation types on the occurrence of hemicryptophytes and phanerophytes (Table 1). In each climate zone, therophytes are frequent on bowé than in woodlands (Fig. 4). Geophytes are frequent in woodlands than on bowe in the semiarid zone while the opposite is found in the sub-humid zone. Chamaephytes are frequent on bowé in the semiarid zone than in the sub-humid zone (Fig. 4).

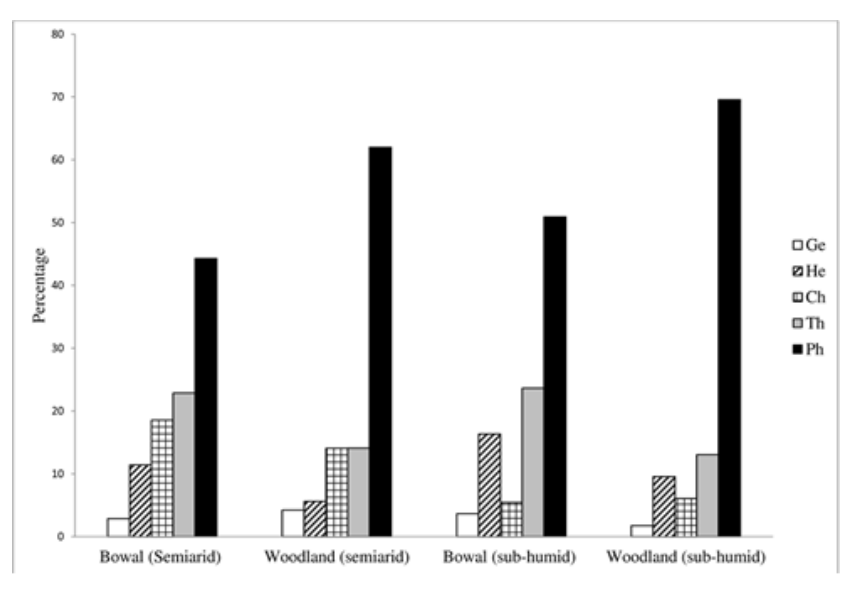

Fig. 4. Plant life forms on bowé and woodland in the two climate zones

Ge: Geophytes; He: hemicryptophytes; Ch: chamaephytes; Th: therophytes; $\mathrm{Ph}$ : phanerophytes.

There is significant difference between the semiarid zone vs. sub-humid zone and bowé vs. woodlands on the occurrence of Afro-Tropical, Afro-American, Guineo-Congolian, Pluri regional African, Pan Tropical, Sudano-Guinean and Sudano-Zambesian (Table 2). The difference between bowé vs. woodlands on the occurrence of Afro-Malgache and Sudanian chorological types is not significant. The interaction between the climate zones and the vegetation types is significant for these chorological types except for Sudanian, Sudano-Guinean and Afro-American. In each climate zone (Fig. 5), Afro-Tropical, Pluri regional African, and Pan Tropical chorological types are frequent on bowe than in woodlands while the opposite is found for Guineo-Congolian and Sudano-Zambesian. However Sudanian and Sudano-Zambesian are frequent in the semiarid zone than the sub-humid zone while the opposite is found for the Sudano-Guinean and Guineo-Congolian chorological types (Fig. 5). We could not conclude that there is an interaction between the climate zones and the vegetation types on the occurrence of Sudanian, Sudano-Guinean and Afro-American chorological types (Table 2). 


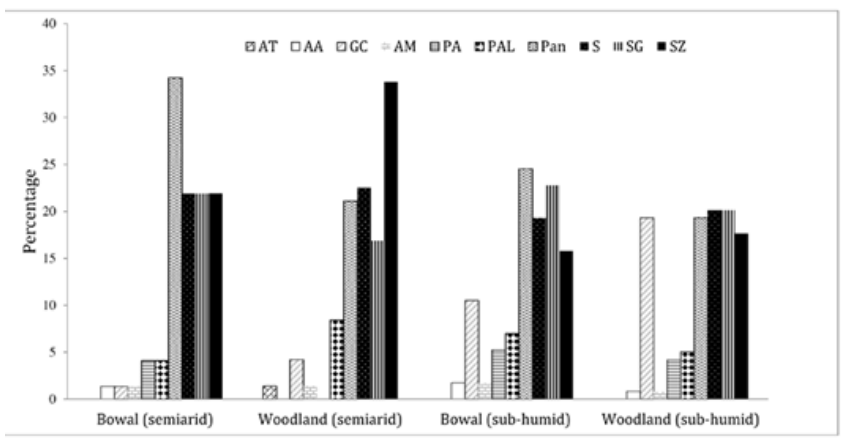

Fig. 5. Plant chorological type on bowé and woodland in the two climate zones

AT: Afro-Tropical; AA: Afro-American; GC: Guineo-Congolian; AM: Afro-Malgache; PA: Pluri regional African; PAL: Paleo Tropical; Pan: Pan Tropical; S: Sudanian; SG: Sudano-Guinean; SZ: Sudano-Zambesian.

\subsection{Life Form and Chorological Type on Bowé}

Regarding life form, geophytes ( $\mathrm{t}$ value $=3.85 ; \mathrm{p}<0.001)$, hemicryptophytes $(\mathrm{t}$ value $=10.71 ; \mathrm{p}<0.001)$ and phanerophytes $(\mathrm{t}$ value $=8.14 ; \mathrm{p}<0.001)$ are significantly less frequent on bowé in the semiarid than in the sub-humid climate zone (Fig. 4) while chamaephytes are more frequent on bowé in the semiarid zone ( $\mathrm{t}$ value $=-38.37$; $\mathrm{p}<0.001$; Fig 4). The difference between the two climate zones on the occurrence of therophytes on bowé is not significant ( $\mathrm{t}$ value $=0.48 ; \mathrm{p}>0.05)$.

Regarding the chorological types, the Sudano-Zambesian $(\mathrm{t}$ value $=-10.78 ; \mathrm{p}<0.001)$, Sudanian $(\mathrm{t}$ value $=-8.60 ; \mathrm{p}<$ 0.001 ) and Pan-Tropical plant chorological types ( $\mathrm{t}$ value $=$ $-16.62 ; \mathrm{p}<0.001)$ are more frequent on bowé in the semiarid climate zone than in the sub-humid zone (Fig. 5). The Guineo-Congolian ( $\mathrm{t}$ value $=52.26 ; \mathrm{p}<0.001)$, Sudano-Guinean $(\mathrm{t}$ value $=3.99 ; \mathrm{p}<0.001)$, Paleo-Tropical $(\mathrm{t}$ value $=3.99 ; \mathrm{p}<0.001)$, Pluri regional African $(\mathrm{t}$ value $=$ $10.17, \mathrm{p}<0.001)$, Afro-American $(\mathrm{t}$ value $=7.162 ; \mathrm{p}<0.001)$ and Afro-Malgache ( $\mathrm{t}$ value $=7.16 ; \mathrm{p}<0.001)$ plant chorological types are less frequent on bowé in the semiarid climate zone than the sub-humid zone (Fig. 5). The difference between bowé in the two climate zones on the occurrence of Afro-Tropical is not significant $(\mathrm{t}$ value $=0.53$; $\mathrm{p}>0.05)$

\section{Discussion}

The vegetation characteristics on bowe in the two climate zones of Benin are identified as grassland and savanna. Comparable findings were made in Burkina Faso [31], Côte d'Ivoire [24] and Mali [17]. The woody species are more frequent on bowe in the sub-humid zone than the semiarid zone. This may be due by the more humid condition observed in the sub-humid climate zone or by less frequent of fires in this zone. Higher humidity leads to higher woody abundance [1] and more the climate is dry more the woody species die [3]. In addition the fire regime also affects the species composition [9]. Thus the differences observed between the plant species compositions on bowé of the two contrasting climate zones indicate that climate and fire regime play an important role for species distribution and in the colonization of bowé by plant species.

Both in general and within the climate zones, the composition of species on bowé is not similar to the one in woodlands. The reason for this may be found in the great frequency of species with large distribution range on bowé (Afro-Tropical, Afro-Malgache, Pluri regional African and Pan Tropical). These species are mostly therophytes well adapted to degraded and poor land [7, 18]. This life form is frequent on bowé in both climate zones.

In woodlands, the Sudano-Zambesian and Sudanian species are more frequent in the semiarid zone and the Sudano-Guinean and Guineo-Congolian species in the sub-humid climate zone. Sudanian and Sudano-Zambesian species characterize and dominate the vegetation of the Sudanian zone where semiarid climate prevail [1, 12], while the Sudano-Guinean and Guineo-Congolian species characterize and dominate the Sudano-Guinean zone [1], where the sub-humid prevails.

\section{Conclusion}

Bowé are characterized in general by grassland and savanna with more frequency of Afro-Tropical, Afro-Malgache, Pluri regional African and Pan Tropical chorological types and therophytes life forms. However there are some differences between the climate zones on the vegetation characteristics on bowé.

In the semiarid climate zone, the dominant woody species on bowé are Acacia macrostachya, Combretum glutinosum, Combretum nigricans, Combretum collinum, Strychnos spinosa, Cassia sieberiana, Ziziphus mucronata, Lannea microcarpa, Anogeissus leiocarpa. The herb layer is dominated by Aristida kerstingii, Loudetiopsis kerstingii, Aristida stipoides, Lepidagathis alopecuroides and Lepidagathis collina.

In the sub-humid climate zone the dominant woody species on bowé are Combretum nigricans, Combretum collinum, Detarium microcarpum, Daniellia oliveri. The dominant herb species are Hyparrhenia welwitschii, Indigofera bracteolata, Oldenlandia corymbosa and Chlorophytum macrophyllum.

Geophytes, hemicryptophyte and phanerophyte life forms are more frequent on bowe in the sub-humid than in the semiarid climate zone while the opposite is found for chamaephytes.

Sudano-Zambesian, Sudanian and Pan-Tropical plant chorological types are more frequent on bowé in the semiarid climate zone than in the sub-humid zone. The Guineo-Congolian, Sudano-Guinean, Paleo-Tropical, Pluri regional African, Afro-American and Afro-Malgache plant chorological types are less frequent on bowé in the semiarid climate zone than the sub-humid zone.

Amaranthaceae, Zingiberaceae, Chrysobalanaceae, Connaraceae, Loganiaceae, Moraceae and Ochnaceae plant families are exclusively found on bowé in the sub-humid climate zone, while Convolvulaceae, Loganiaceae, 
Rhamnaceae, Araceae, Colchicaceae, Cucurbitaceae, Olacaceae, Pedaliaceae, Amaranthaceae, and Cyperaceae are

exclusively found on bowé in semiarid zone.

Table 1. Two way ANOVA results for life forms on bowé and woodland in semiarid and sub-humid climate zones in Benin

\begin{tabular}{|c|c|c|c|c|c|}
\hline Source & Ge & $\mathrm{He}$ & Ch & Th & $\mathbf{P h}$ \\
\hline Semiarid-Sub-humid & $12.13 * * *$ & $289.63 * * *$ & $2562.10 * * *$ & $1.84 \mathrm{~ns}$ & $181.87 * * *$ \\
\hline Bowé-Woodland & $1.09 \mathrm{~ns}$ & $631.50 * * *$ & $158.40 * * *$ & $1605.33 * * *$ & $1031.35^{* * *}$ \\
\hline Interaction & $84.44 * * *$ & $0.63 \mathrm{~ns}$ & $143.50 * * *$ & $4.59 *$ & $0.52 \mathrm{~ns}$ \\
\hline
\end{tabular}

The value is F value; Ge: Geophytes; He: hemicryptophytes; Ch: chamaephytes; Th: therophytes; Ph: phanerophytes ns: non significant at $0.05 ; *$ : significant at $0.05 ; * *$ : significant at $0.01 ; * *$ : significant at 0.001

Table 2. Two way ANOVA results for chorological types on bowé and woodland in semiarid and sub-humid climate zones in Benin

\begin{tabular}{|c|c|c|c|c|c|c|c|c|c|c|}
\hline Source & AT & $\mathbf{A A}$ & GC & $\mathbf{A M}$ & PA & PAL & Pan & $\mathbf{S}$ & SG & SZ \\
\hline Semiarid-Sub-humid & $11.32 * *$ & $85.41 * * *$ & $4218.40 * * *$ & $8.84 * *$ & $538.36 * * *$ & $0.22 \mathrm{~ns}$ & $220.00 * * *$ & $155.78 * * *$ & $53.00 * * *$ & $1034.90 * * *$ \\
\hline Bowé-Woodland & $11.32 * *$ & $67.99 * * *$ & $902.70 * * *$ & $0.48 \mathrm{~ns}$ & $278.10 * * *$ & $47.48 * * *$ & $810.30 * * *$ & $2.783 \mathrm{~ns}$ & $101.68 * * *$ & $720.70 * * *$ \\
\hline Interaction & $5.59 *$ & $1.27 \mathrm{~ns}$ & $262.50 * * *$ & $47.86^{* * *}$ & $62.22 * * *$ & $152.50 * * *$ & $176.50 * * *$ & $0.81 \mathrm{~ns}$ & $0.23 \mathrm{~ns}$ & $252.30 * * *$ \\
\hline
\end{tabular}

The value is F value; AT: Afro-Tropical; AA: Afro-American; GC: Guineo-Congolian; AM: Afro-Malgache; PA: Pluri regional African; PAL: Paleo Tropical; Pan: Pan Tropical; S: Sudanian; SG: Sudano-Guinean; SZ: Sudano-Zambesian. ns: non significant at $0.05 ; *$ : significant at $0.05 ; * *$ : significant at $0.01 ; * *$ : significant at 0.001 .

\section{Acknowledgements}

This work was supported by the Robert S. McNamara Fellowships Program and the UNDESERT (EU FP7 243906), "Understanding and combating desertification to mitigate its impact on ecosystem services" funded by the European Commission, Directorate General for Research and Innovation, Environment Programme for financial support.

\section{References}

[1] Adomou, C., 2006. Phytosociological and chorological approaches to phytogeography: a meso-scale study in Benin. Syst. Geogr. Pl. 76, 155-178.

[2] Aké Assi L., 2001-2002. Flore de la Côte d'Ivoire: catalogue systématique, biogéographie et écologie. Boissiera 57-58, 1-396-1-401.

[3] Allen, D.C., Macalady, K.A., Chenchouni, H., Bachelet, D., McDowell, N., Vennetier, M., Kitzberger, T., Rigling, A., Breshears, D.D., (Ted) Hogg, E.H., Gonzalez, P., Fensham, R., Zhang, Z., Castro, J., Demidova, N., Lim, J-H., Allard, G., Running, S.W., Semerci, A., Cobb, N., 2010. A global overview of drought and heat-induced tree mortality reveals emerging climate change risks for forests. Forest. Ecol. Manag. $259,660-684$

[4] André, V., Pestaña, G., Rossi, G., 2003. Foreign representations and local realities. Mt. Res. Dev. 23, 149-155.

[5] Angiosperm Phylogeny Group (APG), 2003. An update of the Angiosperm Phylogeny Group classification for the orders and families of flowering plants: APG II. Bot. J. Linn. Soc. 141, 399-436.

[6] Aubréville A., 1947. Les brousses secondaires en Afrique équatoriale. Bois et Forêts des Tropiques 2, 24-35.

[7] Calvo, L., Santalla, S., Marcos, E., Valbuena, L., Tarrega, R., Luis, E., 2003. Regeneration after wildfire in communities dominated by Pinus pinaster, an obligate seeder, and in others dominated by Quercus pyrenaica, a typical resprouter. Forest. Ecol. Manag. 184, 209-223.

[8] Chevalier, A., 1909. Les hauts plateaux du Fouta Djalon. Ann. Geogr. 18, 253- 261.

[9] Devineau, J.L., Fournier, A., Nignan, S., 2010. Savanna fire regimes assessment with MODIS fire data: their relationship to land cover and plant species distribution in western Burkina Faso (West Africa). J. Arid. Environ.74, 1092-1101.

[10] Duvall, C., 2011. Ferricrete, forests, and temporal scale in the production of colonial science in Africa. In: Goldman, M.J., Nadasdy, P., Turner, M.D. (Eds.), Knowing nature: conservation at the intersection of political ecology and science studies. The University of Chicago press, Chicago \& London, pp. 113-127.

[11] Garrett, G.H., 1892. Sierra Leone and the interior to the upper waters of the Niger. Proceedings of the Royal Geographical Society $14,433-455$.

[12] Gnoumou, A., Thiombiano, A., Hahn-Hadjali, K., Ababouabou, B., Sarr, M., Guinko, S., 2008. Le Parc Urbain Bangr-Wéoogo: une aire de conservation de la diversité floristique au cœur de la ville de Ouagadougou, Burkina Faso. Flora et Vegetatio Sudano-Sambesica 11, 35-48.

[13] Guinko, S., 1984. Végétation de la Haute-Volta. $\mathrm{PhD}$ thesis, University of Bordeaux, Bordeaux.

[14] Hangelbroek, H.H., Santamaria, L., De Boer, T., 2003. Local adaptation of the pondweed Potamogeton pectinatus to contrasting substrate types mediated by changes in propagule provisioning. J. Ecol. 91, 1081-1092.

[15] Jaccard, P., 1901. Distribution de la flore alpine dans le bassin des Darnes et dans quelques régions voisines. Bull. Soc. Vaud. Sci. Nat. 37, 241-272.

[16] Li, X.R., Jia, X.H., Dong, G.R., 2006. Influence of desertification on vegetation pattern variations in the cold semi-arid grasslands of Qinghai-Tibet Plateau, North-West China. J. Arid. Environ. 64, 505-522. 
[17] Nasi, R., 1994. La végétation du centre régional d'endémisme soudanien au Mali. Etude de la forêt des Monts Mandingues et essaye de synthèse. PhD Thesis, University of Paris, Paris.

[18] Overbeck, G.E., Pfadenhauer, J., 2007. Adaptive strategies in burned subtropical grassland in southern Brazil. Flora 202, 27-49.

[19] Padonou, E.A., Assogbadjo, A.E., Bachmann, Y., Sinsin, B., 2012. How far bowalization affects phytodiversity, life forms and plant morphology in sub-humid tropic in West Africa. Afr. J. Ecol. 51, 255-262.

[20] Padonou, E.A., Fandohan, B., Bachmann, Y., Sinsin, B., 2014. How farmers perceive and cope with bowalization: a case study from West Africa (Benin). Land Use Policy 36, 461- 467.

[21] Padonou, E.A., Bachmann, Y., Glèlè Kakaï, R., Lykke, A.M., Sinsin, B., 2015. Spatial distribution of bowal and differences in physicochemical characteristics between bowal and woodland soils in West Africa (Benin). Catena 124, 45-52.

[22] Pisces Conservation, 2002. Community Analysis Package (CAP), A Program to search for structure in Ecological Community Data, Version 2.0. IRC House, Pennington.

[23] Pobéguin, H., 1906. Essai sur la flore de la Guinée Française. Augustin Challamel, Paris.
[24] Poilecot, P., 1995. Les Poaceae de Côte-d'Ivoire. IUCN, Geneva.

[25] Raunkiaer, C., 1934. The Life Forms of Plants and Statistical Plant Geography. Calderon Press, Oxford.

[26] R Development Core Team, 2005. R: A language and environment for statistical computing. $\mathrm{R}$ Foundation for Statistical Computing, Vienna.

[27] Schlesinger, W.H., Pilmanis, A.M., 1998. Plant-soil interactions in deserts. Biochemistry-US 42, 169-187.

[28] Thomas, W.G., Van Dusen Lewis, J., Dorsey, J., 2004. Guinea agricultural sector assessment. USAID/Guinea Rural and Agricultural Incomes with a Sustainable Environment (RAISE) program, contract PCE -I-00-99-0000I-00. ARD-RAISE Consortium, Arlington.

[29] Thompson, H.N., 1911. The forests of Southern Nigeria. Royal African Society 10, 121-45.

[30] White, 1983. Vegetation map of Africa: a contrasting approach. UNESCO, Paris.

[31] Zwarg, A., Schmidt, M., Janßen, T., Hahn, K., Zizka, G., 2012. Plant diversity, functional traits and soil conditions of grass savannas on lateritic crusts (bowé) in south eastern Burkina Faso. Flora et Vegetatio Sudano-Sambesica 15, 15-24. 